\title{
A Study on the Impact of Rewards and Recognition on Employee Motivation
}

\author{
Dr. Baskar ${ }^{1}$, Prakash Rajkumar. K. $\mathbf{R}^{2}$ \\ ${ }^{1}$ Professor, Dept of MBA, Annamalai University, Chidambaram, Tamilnadu, India \\ ${ }^{2}$ Research Scholar, Annamalai University, Chidambaram-Tamilnadu, India
}

\begin{abstract}
The general objective of the research was to study the impact of rewards and recognition on employee motivation. And the specific objectives were to identify the most effective means of rewards and recognition, to study the behavioral differences between appreciated and non-appreciated employees, to understand the extent to which motivation enhances employee's performance, to identify if the motivation has an effect on individual and organizational growth and to study if rewards and recognition results in emotional conflicts between employees. The descriptive research design was adopted for this study. Various employees from the companies were the respondents. It is evident from the study that a variety of factors influence employee motivation and satisfaction. It was also significant to discover that there is a direct and positive relationship between rewards and recognition and job satisfaction and motivation. Hence, if rewards and recognition offered to employees were to be altered, then there would be a corresponding change in work motivation and satisfaction. The direct translation of this could be that the better the rewards and recognition, the higher the levels of motivation and satisfaction, and possibly therefore, the greater the levels of performance and productivity. In the event of major inconsistencies, especially for emotional conflicts between performers and non performers, the organisation should make an effort to reassess and rectify this situation. In the event that the organisation does not re-assess this situation, it could have a resultant negative impact on job performance and productivity as well as on the retention of minorities. In accordance with Maslow's hierarchy of needs, the lower level needs such as salary and benefits must first be met before the higher level needs, which impacts motivation can be satisfied. The research study has shown that managers can employ different strategies to motivate employees, but that it is important that managers keep in mind that different strategies would have a different motivational impact on different people. To get optimum results from a motivational strategy, the manager has to realise and understand issues, which requires recognition of each individual's unique values, beliefs and practices.
\end{abstract}

Keywords: Rewards, Recognition, Employee, motivation

\section{Introduction}

As manpower constitute the core of any business and ultimately employees are the main focus of human resource management, with the constant changes occurring in the world today, especially with regards to technology and innovation, there is a need for companies to reassess the manner in which they communicate to their employees, which would increase their morale and will act as a driving force towards an integrated workforce. Thus, apart from financial compensations there are other means to reward employees, some of which include the praise that employees are able to acquire from their managers, the opportunity to take on important projects or tasks, and even leadership attention which helps them climb Maslow's pyramid of needs to attain motivation for better performance.

Employee recognition is a judgment on a worker's contribution, in terms of the work process as well as dedication and motivation. It also involves evaluating and acknowledging the results of this work. In short, it looks at the unique contribution of each worker and stresses the value of his or her professional expertise and experience. By creating a culture of recognition, employees become more engaged. Engaged employees are happy, loyal, and productive. Everyday there is an opportunity to recognize someone for their service without spending a lot of money. Informal rewards are the icing on the cake that keeps employees motivated, engaged, and coming back for more. But it is also essential to study and understand the extent to which the above mentioned factors have an impact on the work force considering all the positive and negative effects appreciations have on individual and organizational growth.

The primary need of the study is to introduce innovative methods of appreciations for employees. The study would help companies frame newer employee engagement programs. It would help researchers in future to analyze trends in employee engagement.

\section{Conceptual Definition}

Reward: Jack Zigon defines rewards as "something than increases the frequency of an employee action" (1998).

Recognition: It is constructive, genuine feedback based on acknowledging people as sincere, worthy of respect, having needs, and equipped with their own personal expertise. (Brun \& Dugas, 2002).

Motivation: Abraham Maslow (1954) defines motivation as the Cognitive, Aesthetic and Transcendence aspects, which drives a man towards a developmental change

\section{Operational Definition}

Reward: A formal, impartial, and equitable exchange. A material or financial expression of appreciation that is conditional on results. 


\section{International Journal of Science and Research (IJSR) \\ ISSN (Online): 2319-7064 \\ Index Copernicus Value (2013): 6.14 | Impact Factor (2014): 5.611}

Recognition: A relationship between two or more people. Recognition is a return on an employee's effort and dedication at work, as well as his or her results.

Motivation: It is the process of boosting the morale of employees to encourage them to willingly give their best in accomplishing assigned tasks.

\section{Company Profile}

Aloft is a chain of SPG group in India. Currently, there are 214 stores across 90 cities and towns in India. Aloft Hotels is a brand of hotels based out of North America. Its parent company is Starwood Hotels \& Resorts Worldwide, although it is referred to as "a vision of W Hotels". The concept was developed in 2005 . The hotel chain already had many brands, including Sheraton, Westin, and W Hotels, but was looking to expand into a market of more contemporary hotels, which would eventually become known as boutique hotels. To reflect its relationship with Starwood Hotels, the Aloft brand was dubbed as "A Vision of W Hotels". Starwood worked with the architectural company Rockwell Group and its founder David Rockwell to come up with the design.

A defining attribute of the Aloft Hotel brand is its unique, non-traditional style. Starwood has promoted the hotel chain as a new "lifestyle brand," emphasizing a modern and fresh look and a social atmosphere, which encourages guests to spend time in lobby and meet other people.

\section{Rewards and Recognitions' Impact on Employee Motivation}

The focus of this heading is to provide insights to the theories that have shaped the understanding of motivation, by focussing on the content theories of motivation. The chapter proceeds with an in-depth presentation of a total rewards management programme and the support that a performance management process can provide to such a programme. Given the focus of this research study, it is important to have a sound understanding of the meaning of rewards and recognition, as they are often used interchangeably, but the literature indicates that there are unique, tangible differences between these concepts.

Organisations are under constant pressure to enhance and improve their performance and are realising that an interdependent relationship exists between organisational performance and employee performance. In the following chapter the focus will be on the motivational theories and the impact that these theories have on enhancing employee performance. Increasingly, organizations are realizing that they have to establish an equitable balance between the employee's contribution to the organization and the organization's contribution to the employee. Establishing this balance is one of the main reasons to reward employees.

Organizations that follow a strategic approach to creating this balance focus on the three main components of a reward system, which includes, compensation, benefits and recognition. Studies that have been conducted on the topic indicates that the most common problem in organizations today is that they miss the important component of Reward, which is the low-cost, high-return ingredient to a wellbalanced reward system. A key focus of recognition is to make employees feel appreciated and valued. Research has proven that employees who get recognized tend to have higher self esteem, more confidence, more willingness to take on new challenges and more eagerness to be innovative. Reward system is an important tool that management can use to channel employee motivation in desired ways. In other words, reward systems seek to attract people to join the organization to keep them coming to work, and motivate them to perform to high levels. The reward system consists of all organization components - including people processes rules and decision making activities involved in the allocation of compensation and benefits to employees in exchange for their contribution to the organization. In this chapter we can find the basic conceptual understanding of rewards and recognition and also the citations of various researches on the same.

\section{Important Distinctions}

Recognition is highly akin to the concepts of consideration and reward. We must therefore draw a distinction among these concepts in order to clearly identify what qualifies as recognition. To this end, we will use the indifference/compensation continuum LEVELS

Indifference: A contractual tie between an individual and an organization.

Consideration: A social tie between a human being and an organization. Employees are perceived as thinking and dignified human beings.

Recognition: A relationship between two or more people. Recognition is a return on an employee's effort and dedication at work, as well as his or her results.

Reward: A formal, impartial, and equitable exchange. A material or financial expression of appreciation that is conditional on results.

Compensation: The most formal expression of interest: a regular monetary reward

\section{Research Methodology}

\subsection{Research objectives}

The general objective of the research was to study the impact of rewards and recognition on employee motivation. And the specific objectives were to identify the most effective means of rewards and recognition, to study the behavioral differences between appreciated and nonappreciated employees, to understand the extent to which motivation enhances employee's performance, to identify if the motivation has an effect on individual and organizational growth and to study if rewards and recognition results in emotional conflicts between employees. 


\section{International Journal of Science and Research (IJSR) \\ ISSN (Online): 2319-7064 \\ Index Copernicus Value (2013): 6.14 | Impact Factor (2014): 5.611}

\subsection{Research Design}

The descriptive research design was adopted for this study It describes data and characteristics about the phenomenon being studied. Descriptive research answers the questions who, what, where, when and how. It is a scientific method which involves observing and describing the behavior of a subject without influencing it in any way. Since there has been various researches conducted on rewards and recognitions by various researchers the descriptive design was adopted as the researcher intended only to project the scenario and describe the phenomenon.

\subsection{Universe}

Various employees from the companies were the respondents.

\subsection{Sample Size \& Sample Design}

50 employees were taken as the sample size by using 'convenience sampling' design was adopted as the respondents were selected by researcher on the base of ease of access with which he was comfortable.

\subsection{Tools of Data Collection}

A questionnaire was prepared to collect data from the employees on the various aspects of rewards and recognition desired by the researcher.

\section{Source of Data Collection}

\subsection{Primary data}

It comprises of the data which was collected through the questionnaires filled by the respondents.

\subsection{Secondary data}

It comprises of the data which was collected through books, journals, articles, magazines and websites.

\section{Pre Testing}

The researcher gave a tentative questionnaire with limited number of questions to 10 respondents and studied the authenticity of the data collected to make further changes if required. It was done before the dates of data collection and there were no changes done.

\section{Tools Used}

Tabular column, percentage method, Chi-square test, correlation etc

\section{Findings}

The data collected by the researcher on 'the study on the impact of rewards and recognition on employee motivation'. The data were collected from employees of study area. The data were analyzed after the formulation of a code book and a code sheet in a systematic representation. The followings were the findings

\section{Methods of Reward Policies}

- $52 \%$ of the respondents' organizations follow both formal and informal methods of reward policies.

- $42 \%$ of the respondents' organizations give employee of the month award.

- $26 \%$ of the respondents' organizations carried out praising staff publicly at staff and other public meetings as informal rewards and recognition.

- $60 \%$ of the respondents' organizations had rewards and recognition program on a monthly basis.

\section{Mode of Recognizing Performers}

- $56 \%$ of rewards and recognition are based on a combination of innovative and creative ideas, increased productivity and customer satisfaction.

- $42 \%$ of the respondents' companies use group vote, decision from top officials and decision from single manager as the mode of judgment for rewards and recognition

- $38 \%$ of the respondents feel that promotion based on performance is the most effective way of rewarding an employee.

\section{Treatment of Non-Performers}

- $44 \%$ of the respondents said that training for skill development was given for non-performers.

- $28 \%$ of the respondents said that non-performers who did not show improvement where terminated from their respective jobs.

\section{Various Impacts of Rewards and Recognitions}

- $46 \%$ of the respondents strongly agree that employee's performance increases after rewards and recognition.

- $38 \%$ of the respondents were neutral on the fact that rewards and recognition instigates attitude or over confidence in the employee.

- $42 \%$ of the respondents agree that non appreciated employees are isolated from appreciated employees.

- $46 \%$ of the respondents agree that job satisfaction increases motivation.

- $52 \%$ of the respondents strongly agree that rewards and recognition increases motivation.

- $48 \%$ of the respondents agree that an employee puts extra effort in order to attain rewards and recognition.

- $38 \%$ of the respondents agree that rewards and recognition collides individual and organizational growth.

- $36 \%$ of the respondents agree that rewards and recognition increases employee loyalty towards the organization.

- $36 \%$ of the respondents felt that the major benefit a company receives out of rewards and recognition is increased level of motivation. 


\section{International Journal of Science and Research (IJSR) \\ ISSN (Online): 2319-7064}

Index Copernicus Value (2013): 6.14 | Impact Factor (2014): 5.611

- $48 \%$ of the respondents agree that rewarded employees show high performance consistence. .

- $58 \%$ of the respondents felt that rewards and recognition should be given in front of the entire company.

- $52 \%$ of the respondents felt that rewards and recognition should be given by their immediate manager or supervisor.

- $48 \%$ of the employees agree that rewards and recognitions results in emotional conflicts between performers and non-performers.

1.1 Table showing relationship between after recognition and sense of achievement Case Processing Summary

\begin{tabular}{|c|c|c|c|c|c|c|}
\hline & \multicolumn{6}{|c|}{ Cases } \\
\hline & \multicolumn{2}{|r|}{ Valid } & \multicolumn{2}{|c|}{ Missing } & \multicolumn{2}{|r|}{ Total } \\
\hline & $N$ & Percent & $N$ & Percent & $N$ & Percent \\
\hline $\begin{array}{l}\text { After recognition } \\
\text { drastic } \\
\text { improvement } * \\
\text { motivated by } \\
\text { sense of } \\
\text { achievement }\end{array}$ & 50 & $100.00 \%$ & 0 & $0.00 \%$ & 50 & $100.00 \%$ \\
\hline
\end{tabular}

1.2 After recognition drastic improvement * motivated by sense of achievement Cross tabulation

\begin{tabular}{|c|c|c|c|c|c|c|}
\hline \multirow{2}{*}{\multicolumn{2}{|c|}{ Count }} & \multicolumn{4}{|c|}{$\begin{array}{c}\text { Motivated by sense of } \\
\text { achievement }\end{array}$} & \multirow[b]{2}{*}{ Total } \\
\hline & & $\begin{array}{c}\text { strongly } \\
\text { agree }\end{array}$ & agree & neutral & disagree & \\
\hline \multicolumn{2}{|c|}{ After recognition strongly } & & & & & \\
\hline \multirow{3}{*}{$\begin{array}{c}\text { drastic } \\
\text { improvement }\end{array}$} & agree & 2 & 8 & 0 & 1 & 11 \\
\hline & agree & 5 & 12 & 2 & 0 & 19 \\
\hline & neutral & 3 & 8 & 5 & 4 & 20 \\
\hline \multicolumn{2}{|l|}{ Total } & 10 & 28 & 7 & 5 & 50 \\
\hline
\end{tabular}

1.3 Chi-Square Tests

\begin{tabular}{|c|c|c|c|}
\hline & Value & df & A symp. Sig. (2-sided) \\
\hline Pearson Chi-Square & $9.626^{\mathrm{a}}$ & 6 & 0.141 \\
\hline Likelihood Ratio & 12.334 & 6 & 0.055 \\
\hline $\begin{array}{c}\text { Linear-by-Linear } \\
\text { Association }\end{array}$ & 3.537 & 1 & 0.06 \\
\hline N of Valid Cases & 50 & & \\
\hline
\end{tabular}

a. 9 cells $(75.0 \%)$ have expected count less than 5 . The minimum expected count is 1.10 .

\section{Interpretation}

The above table shows that of chi square calculated to find whether significant relationship between motivated by the recognition you receive and you put extra effort in order to achieve a reward or recognition in their company. As the $\mathrm{p}=0.141$ greater than the level of the significant so we accept the null hypothesis and there is no significant relationship between Recognition and the employees extra effort to achieve the reward in the organization.
1.4. Table showing relationship between treatment of non-performers and motivation

\begin{tabular}{|c|c|c|c|}
\hline \multicolumn{1}{|c|}{ Correlations } & $\begin{array}{c}\text { Non- } \\
\text { performers } \\
\text { treated }\end{array}$ & $\begin{array}{c}\text { Motivated } \\
\text { by } \\
\text { recognition }\end{array}$ \\
\hline \multirow{2}{*}{$\begin{array}{c}\text { Non-performers } \\
\text { treated }\end{array}$} & Pearson Correlation & 1 & 0.27 \\
\cline { 2 - 4 } & Sig. (2-tailed) & & 0.058 \\
\cline { 2 - 4 } & $\mathrm{N}$ & 50 & 50 \\
\hline $\begin{array}{c}\text { Motivated by } \\
\text { recognition }\end{array}$ & Pearson Correlation & 0.27 & 1 \\
\cline { 2 - 4 } & Sig. (2-tailed) & 0.058 & \\
\cline { 2 - 4 } & $\mathrm{N}$ & 50 & 50 \\
\hline
\end{tabular}

\section{Interpretation}

The above the table show that of chi square calculated to find whether significant relationship between employee motivation and the effort to achieve the rewards or recognition on their company. As the $p=0.141$ greater than the level of the significant so we accept the null hypothesis .there is no significant relationship between the non performing employees and motivation.

\section{Conclusion}

It is evident from the study that a variety of factors influence employee motivation and satisfaction. It was also significant to discover that there is a direct and positive relationship between rewards and recognition and job satisfaction and motivation. Hence, if rewards and recognition offered to employees were to be altered, then there would be a corresponding change in work motivation and satisfaction. The direct translation of this could be that the better the rewards and recognition, the higher the levels of motivation and satisfaction, and possibly therefore, the greater the levels of performance and productivity. In the event of major inconsistencies, especially for emotional conflicts between performers and non performers, the organisation should make an effort to re-assess and rectify this situation. In the event that the organisation does not re-assess this situation, it could have a resultant negative impact on job performance and productivity as well as on the retention of minorities. In accordance with Maslow's hierarchy of needs, the lower level needs such as salary and benefits must first be met before the higher level needs, which impacts motivation can be satisfied.

The findings alluded to the fact that employees with no awards tended to be less motivated. Given the fact that the organisation and thus the business unit is in a state of transformation, employees in this category may want to quit the organization. This places the business unit under pressure to retain these employees. The business unit could benefit from implementing a retention strategy, which in itself has a strong focus on recognition. As mentioned previously, reward and recognition if improved could have a positive effect on motivation and satisfaction. The research indicates that recognition includes acknowledgement and performance feedback. Managers in the business unit could thus use the performance management system to provide regular acknowledgement and feedback. 


\section{International Journal of Science and Research (IJSR) \\ ISSN (Online): 2319-7064 \\ Index Copernicus Value (2013): 6.14 | Impact Factor (2014): 5.611}

The research study has shown that managers can employ different strategies to motivate employees, but that it is important that managers keep in mind that different strategies would have a different motivational impact on different people. To get optimum results from a motivational strategy, the manager has to realise and understand issues, which requires recognition of each individual's unique values, beliefs and practices. Important to consider is that different motivation strategies may affect an employee in different ways at different points in time because conditions, needs and personal objectives are not static but in constant state of fluctuation.

\section{Suggestions}

- Many different things motivate people, and that which motivates one person may not necessarily motivate another. Thus companies should take into account the interests of all the employees.

- Since most of the employees demand monetary benefit in rewards and recognition, organizations should adopt more financial incentives for rewarding the employees.

- If the above mentioned suggestion hinders the budget, innovative ways of low-cost recognition programmes can be organised. Which can be,

1) Post on 'recognition board,' bulletin board, newsletters, web site.

2) Hall of Fame - pictures of employees

3) Submitting article to Intranet for agency viewing

4) Submitting article to local/regional/national newspaper regarding employee's achievement.

5) Scrapbook with pictures of achievements throughout the year

6) Senior manager attending a staff meeting when employees are recognized for their achievements.

- All levels of mangers should be trained on the art of making all the employees feel comfortable in the working environment which does not result in emotional conflicts between performers and non performers. It can be done by,

1) Providing employees an understanding on how they can impact the organization's goals and drive the business to success.

2) Discussing the approach for managing and rewarding both individual and team performance.

3) Explaining how the program works and how employees can receive recognition.

4) Learning ways to motivate and inspire others.

5) Learning how to communicate needs, expectations, and goals clearly.

\section{Limitations}

The researcher was given a very limited time to conduct the study on the employees. The researcher also faced difficulty in getting the respondents as many of them were not present in their work place. The researcher felt that getting the respondents was time consuming. The cost involved to do the research was more. The shift timings were another barrier to get the respondents. It may be a prerequisite to approach various organizations which is ultimately a time consuming factor. Respondents who have not received rewards or recognition may show discomfort in filling the questionnaires.

\section{References}

[1] Allen, R. \& Helms, M., (Fall 2002). Employee perceptions of relationships between strategy rewards and organizational performance. Journal of Business Strategies, 19 (2). 115-139.

[2] Dunham, K., (December 16, 2003). Career journal: companies offer spa days, gifts to reward, retain employees. Wall Street Journal, (B8). Retrieved February 4, 2004, from http://80-proquest.umi.com.

[3] Jimenez, R., (October 1999). Managing employee retention through RECOGNITION. T+D, 53 (10). 53-55.

[4] Karl Heslop(2005), The relationship between rewards, regognition and motivation at an insurance company in the Western Cape.

[5] Keller, J. (1999). Motivational Systems. In H.D. Stolovitch\& E. J. Keeps, (Eds.), Handbook of human performance technology. (pp. 373-394). San Francisco: Jossey-Bass Pfeiffer.

[6] Lynch, L., (December 2003). Keeping the best: the difference between retaining and losing top staff talent is leadership. Association Management, 55 (13). Retrieved January 16, 2004 from http://nexis.com.

[7] Nelson, B., (January 2004). Everything you thought you knew about recognition is wrong. Workplace Management. Retrieved February 16, 2004 from http://www.workforce.com.

[8] Puwanenthiren Pratheep kanth., Reward System And Its Impact On Employee Motivation In Commercial Bank Of Sri Lanka Plc, In Jaffna District. Global Journal of Management and Business Research - Volume 11 Issue 4 Version 1.0 March 2011

[9] Shutan, B., (September 2003). Massaging morale. Incentive, 177 (9). 96.

[10]Zigon, J., (1998). Rewards and performance incentives. Retrieved February 15, 2004 